\title{
FATALISM AND ANOMIE: COMPONENTS OF RURAL-URBAN DIFFERENCES
}

\author{
Sakari Sariola \\ University of Kansas
}

This paper is concerned with the possibility of applying Durkheim's all but ignored notion on fatalism in a study of two Colombian peasant villages, in an attempt to work towards a conceptual framework useful in explaining underdevelopment.*

Throughout Durkheim's The Division of Labor runs the theme of the emergence of the individual conscience ${ }^{1}$ which in the modern, differentiated society is replacing the monolithic collective conscience. Religion, before all, ceases to function as the all-embracing source of regulation; it becomes distant and indeterminate; more leeway is given to the display of individually generated forces. Religious norms begin to resemble mere habits of talk; the individual "feels himself less acted upon; he becomes more a source of spontaneous activity." 2

Two Durkheimian types of "norm states," or relationships between the collective conscience and the individual conscience, are of particular interest here. Anomie is the case of disturbances in the collective order of norms which occurs in times of rapid change. ${ }^{3}$ A new set of collective norms is slow in forming, and individuals at the

\footnotetext{
* The interviews for this study were made by the 28 participants in the Curso Internacional de Sociología Rural organized in Medellin during the September 19 to October 28,1961, under the auspices of the Organization of American States, with the directorship of the Northern and Andean Zones of the Interamerican Institute of Agricultural Sciences, Project 39 of the O.A.S., in collaboration with the Faculties of Agronomy and Sociology of the National University of Colombia. I acknowledge the cooperation by $\mathrm{Mr}$. Roy A. Clifford, the director of the course, which made it possible to incorporate the study, the preparation of questionnaires, and field work, as an integral part of the course.
}

transitory period are left upon their own divergent, unchecked "appetites" in competing for social and economic rewards. 4 Fatalism is the case of the individual conscience being captive of alien, extra-systemic manipulation and regulation. 5 The source of regulatory power for norms in the state of fatalism is outside the individual and outside the social aggregate in which he participates.6 Regulation from without contradicts and outweighs the tendencies endogeneously generated. The distinction between anomie and fatalism thus seems to focus on individuals having or not having participating functional control, or consciousness of such control, over the agents of change upon whom their destinies depend. ${ }^{7}$

Some recent writers have chosen to explain the rural unrest appearing in some of the less industrialized societies as an expression of anomie. 8 It seems to the present writer that the theory of anomie, if applied to a relatively stagnated traditional situation and separated from the model of internal differentiation, is likely to become diffuse and sterile. Atomization, the increasing degree of specialization, and institutional complexity are societal correlates of anomie. Fatalism, in contrast, is a conceptual model useful in explaining a societal situation where the internal, endogeneous processes producing change in the subjected system are slow or lacking and the prevailing system of equilibrium can be explained only with reference to the effects upon it from external sources, from an outside system. 
It is the intention of the present writer to defend the proposition that violence and rural despair in many areas of Latin America should be linked with fatalism rather than anomie, and that sociological theory will gain in precision if the original anomie-fatalism dichotomy is maintained and conceptually clarified. A related proposition is maintained that the often-heard allusion to the emergence in the rural areas of Latin America of a new, self-asserting type of individualism, more and more incongruent with the rigid barriers of the agrarian ladder, the internally generated, spontaneous rise of new expectations demanding parity with the progress of the industrial centers, similarly seems to leave unexplained the directionless aggressiveness of the guerillas, and the characteristically blind display of brutalities recorded. ${ }^{10}$

Some preliminary conceptual clarifications are due here. The distinction between internal and external sources of control has meaning only if the conceptual construct of system is accepted. The term system is an analytical means to delineate areas of phenomena within which the component processes are treated as interrelated. The interrelations are described as occurring between "parts" and "wholes." The parts described as pertaining to the same system whole relate to each other and the system whole in terms of internal functional sequences or internal functional covariances; the system itself in relation to its background is described as an acting, relatively self-sustaining and relatively closed totality. Systemic interdependence may be examined either as a systemic configuration of means, i.e., the existing circumstances, assets, possessions, and facts which describe the system contents, or as systemic rules of correspondence regarding the relationship of the means to the goals they serve, i.e., the sets of purposes and meanings which make up the system rationale. Whereas the functional interrelatedness within the system boundaries is seen as conducive to a largely self-sustaining and relatively well-integrated, "seamless," whole, discontinuities of meaning are expected to occur along system boundaries. Agreement on system rationale, in other words, serves as an essential criterion of whether a configuration of means-ends actually constitutes a system of its own, separate from background systems.
Anomia as a mode of personality adaptation departs from the postulate of the individual having internalized the prevailing system rationale prior to its becoming transformed and thus incomprehensible. Potentially or effectively the actor is a component part in the system undergoing transformation. One single system, in other words, is needed to construct the aromic model. The growing internal complexity of the differentiating system results in increasing difficulty to consistently comply with the cultural norms and to fully internalize them. The consequent feelings of deprivation and inadequacy are projected inwards. The residuum of cultural norms, as Merton has put it, tends to "induce personality tensions and conflict, with some measure of ambivalence...Guilt feelings, a sense of sin, pangs of conscience are diverse.terms referring to this unrelieved tension." "Fatalism, in turn, is a two-system model, where two system rationales overlap. The fatalistic rationale is initially unprepared to account for and to comply with the functional "official" rules of sequence and covariance of the domineering system since these were never fully internalized. Status quo in one's own system, and the improvement and impairment of it, are seen as results of the workings of extra-systemic agents. Acute feelings of deprivation are consequently projected outwards rather than inwards. Diffuse and unpredictable revolt against the alleged exterior agents of evil destiny rather than guilt feelings projected towards the self are likely to ensue.

The following study departs from the assumption that fatalism as a state of personality adjustment is characteristic of the isolated folk culture. It is recognizable in cognitive emphasis on the sacred, supraindividual, and hereditary "outside" determinants of individual destiny rather than the actor-centered and systemcentered rationale which gives primacy to individual learning, adaptation, self-help and voluntarism. Fatalism signifies the individual interpreting his life experiences in interaction with postulated extra-systemic, distant agents largely unverifiable through empirical observation and incompatible with the notion of being subject to control by personal effort, individual achievement, planning, and learned techniques of adaptation to the environment. Change from the rural environment to the urban might result in a lessening of deprivations and can be expected 
to enhance the individual's confidence in his capacity to control his welfare, to induce notions of ego-involvement, self-assertion, and perhaps higher aspiration levels than before, but also to introduce the anomic tendencies to blame the individual rather than outside agencies for failure. Urban contacts emerging, for example, in marketing farm produce, social contacts with the city, and knowledge of a greater range of rewards earned in the diversified roles in the city as compared to the village, may provide for a setting where the fatalistic rationale can be expected to change into an actor-centered rationale.

\section{RESEARCH LOCALITIES}

A total of 143 interviews were completed for this study, * 60 in Jamund1, a farm village of dispersed type of settlement 17 miles from the city of Medellín, and 83 in El Zarzal, a village with physical characteristics similar to those of Jamundí, situated along the asphalted superhighway leading to Medellín and about 15 miles from the city. The two villages prior to the study were described by local farm extension workers as "somehow different," but they were both classified as "typical of depressed rural areas." The two villages were clearly different, however, only with respect to the relative ease of access to Medellín: Jamundí was separated from its municipal center of Girardota by a mile of accidented dirt road suitable for traffic by motor vehicle during the dry season only; from Girardota to the superhighway there was another mile of earth road transitable throughout the year. In contrast, there was easy access to Medellín from El Zarzal; buses to the city made a stop in the outskirts of the village area. The social and economic ties connecting Jamundí with the outside reached principally towards the municipal center of Girardota and relatively seldom to Medellín, whereas the peasants in El Zarzal communicated directly and frequently with $\mathrm{Me}-$ dellín. Only 24 per cent of the respondents in Jamundí, as against 56 per cent in El Zarzal, had visited Medellín within the week before the interview-a very significant difference (Table 1 ). Since the interviews were made towards the end of the dry season, the relative isolation of the inhabitants of Jamundí probably increased even more during the rest of the year. Upon being asked to mention the names of three persons "most interested in solving the problems of the village," out of the total of 162 names mentioned, in Jamundí only three names of persons residing outside the village were mentioned; in answer to the same question the respondents in El Zarzal, among the total of 180 names mentioned, gave the names of 36 persons living outside the vill-

TABLE 1. Chi-Square Test of Significance of Differences Between Selected Socioeconomic and Demographic Variables in Jamundi and El Zarzal

$\begin{array}{lccc} & \mathrm{X}^{2} & \text { d.f. } & \text { P } \\ \text { Most recent visit to Medellin } & 20.555 & 4 & .001 \\ \text { Wearing shoes } & 23.967 & 1 & .001 \\ \text { Packed-earth floor } & 12.016 & 1 & .001 \\ \text { Number of cows owned } & 12.865 & 2 & .01 \\ \text { Radios } & 7.544 & 1 & .01 \\ \text { Quantity of milk consumed } & 10.934 & 3 & .02 \\ \text { Sewing machines } & 2.651 & 1 & .20 \\ \text { Quantity of meat consumed } & 1.253 & 4 & .70 \\ \text { Number of rooms } & 2.841 & 4 & .70 \\ \text { Years of formal schooling } & 8.550 & 7 & .30 \\ \text { nliteracy } & 1.330 & 1 & .30 \\ \text { Frequency of reading newspapers } & 6.766 & 4 & .20 \\ \text { Number of female heads of family } & 3.264 & 1 & .10 \\ \text { Age of the head of family } & 6.729 & 4 & .20 \\ \text { Number of children living with family } & 2.686 & 3 & .50 \\ \text { Number of persons living in household } & 3.912 & 7 & .90 \\ \text { Number of years since assuming residence } & 12.372 & 3 & .01\end{array}$


age; a majority of 33 of these in Medellín.

In Jamundí 57 per cent of the respondents had a median of one cuadra (1.6 acres) of own land; in El Zarzal 63 per cent of the respondents had a median of 1.5 cuadras $(2.4$ acres); the rest, 24 per cent of the respondents in Jamundí as against 21 per cent in El Zarzal cultivated or administered lands that belonged to others; 12 per cent in Jamundí as against 7 per cent in El Zarzal were farm workers; 7 per cent in Jamundí as against 9 per cent in El Zarzal had nonfarming occupations. The patterns of farm tenure in the two villages were thus substantially alike. In both villages farming for subsistence was predominant, and in both villages the peasants worked as. a rule as field hands on nearby farms, generally up to the age of 65 years or more. Only one farmowner in Jamundí less than 65 years in age as against 8 farmowners in $\mathrm{E} 1$ Zarzal below the same age limit had enough land to make a living in full-time farming of owned lands.

In socioeconomic measurement El Zarzal was, partially at least, ahead of Jamundí. From among a sample of items given in Table 1, the respondents in El Zarzal wore shoes significantly more often at the time of the interview; their houses had packed-earth floor significantly less frequently; they owned a significantly larger number of cows; significantly more families in El Zarzal had radios; and they consumed on the average more milk per person. The respondents in El Zarzal had slightly but not significantly more sewing machines; they reported consuming meat per week per person in quantities which were on the average not significantly larger than those reported by the respondents in Jamundí; and also the number of rooms in the dwellings in El . Zarzal was approximately the same as in Jamundí.

On the other hand, the respondents in Jamundí, as compared with those in El Zarzal, had on the average a slightly larger number of years of formal schooling; especially there were in Jamundí proportionately more respondents who had from five to six years of formal schooling. The differences in the extent of formal education, however, were statistically not significant. There was no statistically significant difference in the proportion of respondents in the two villages who did not know how to read and write. The respondents in E1 Zarzal reported reading newspapers slightly but not significanly more frequently than those in Jamundí.

A slightly but not significantly larger proportion of the respondents in Jamundí as compared with those in El Zarzal were female heads of family. There were slightly but not significantly more heads of family interviewed in Jamundr in comparison with El Zarzal who were 60 years or more in age. Proportionally fewer families in Jamundí as compared with El Zarzal had children living with the family; the proportion of big families with five or more children tended to be slightly higher in Jamundí. These differences however, were statistically not significant. The number of persons living in the respondent's household was approximately the same in each of the two villages. A significantly larger proportion of the families in El Zarzal as compared with those in Jamundí had moved to live in the village during the past ten years. Four heads of family in El Zarzal had been born in Medellín; the rest in both villages had been born in rural areas, the great majority in the Department of Antioquía, the capital of which is Medellín. Approximately the same proportion of the respondents in both villages, nearly one-third of them, had been born in the village where they now lived.

Despite the mentioned differences between the two villages in socio-economic measurement, there seemed to be grounds to proceed with the analysis under the assumption that the only difference of essential consequence was the intensity of social and economic ties with the city.

Three types of questions were formulated and used in this study to explore the cognitive aspects of fatalism: First, an open-end question ("Two brothers, Juan and Pedro, received farms of the same size, in inheritance from their father. The farms were equally good in quality. Within a few years Juan's farm prospers, but Pedro lives in poverty. In your opinion, how can it be explained that one farmer like Juan prospers while another one does not succeed, in the same conditions? Mention three different causes."); second, multiple-choice questions (e.g., "Which of the following things do you believe most important in order to have good crops: Dedication to work - Knowledge of farming - The Saint of your devotion-Luck-Weather-Others specified?"); third, dichotomous choice ques- 
tions (e.g., "Which of the following statements corresponds better to your way of thinking? The destiny of man is written - Man is the master of his own destiny?"')

The answers obtained to the open-end question are shown in Table 2. It appears that "luck" was the item most frequently and approximately equally often mentioned in both localities. The respondents in Jamundí mentioned significantly more often the will of God and moral strength and weakness (includes alsopersonality, good or bad sentiments, envy, and laziness). The respondents in E1 Zarzal mentioned significantly more frequently administration (includes also organization and planning). Hard work was more frequently but not significantly more frequently mentioned in Jamundí than El Zarzal. ${ }^{12}$

The answers to the questions of multiplechoice type (See Table 3) indicated that the respondents in Jamundí in comparison with the respondents in El Zarzal tended to endorse more often the answer "The Saint of your devotion" and less frequently "knowledge of farming" and "weather," but these differences were statistically not significant. Upon being asked "Which do you believe to be more important for one's welfare - the family lineage or one's own effort?" the large majority of the respondents in both villages endorsed the answer "own effort," without any statistically significant difference being found between the two groups. Approximately the same proportion of respondents in both groups gave the answer "The destiny of man is written" instead of the answer "Man is the master of his destiny." However, a significantly larger proportion of respondents in El Zarzal as compared with those in Jamundí endorsed the alternative "Acquiescence (Spanish "conformidad") is more important in life than struggle (Spanish "lucha")." Comments by the respondents on this item suggested that the wording of the question might have led some to think of "struggle" as something synonymous with "hard work," and that this question might have measured a dimension other than it was intended to measure.

Taking into account all answers to the questionnaire items used, the respondents in Jamundí as compared with those in El Zarzal made a significantly larger number of references to God (Table 3). On the other hand, counting in the same manner the total of references to luck, no significant difference was found between the two groups.

TABLE 2. Mention of Specified Items in Answer to Question on Causes of Success and Failure in the Two Villages, and the P Level Significance of Difference

Item

1. Luck

2. Hard Work

3. Vice

4. Will of God

5. Administration

6. Intelligence

7. Thriftiness

8. Basic Character*

9. Moral Strength and Weakness

10. Knowhow in Farming

11. Seed, Weather, Sickness, Aid Received
No. of Times

Mentioned in

Jamundi $(\mathrm{N}=58)$
No. of Times

Mentioned in

El Zarzal $(\mathrm{N}=79)$
P Level of Significance of the Difference

$\begin{array}{rrr}43 & 57 & .80 \\ 30 & 28 & .10 \\ 16 & 25 & .70 \\ 22 & 17 & .05 \\ 7 & 24 & .02 \\ 9 & 15 & .70 \\ 6 & 15 & .20 \\ 7 & 5 & .30 \\ 9 & & .02 \\ 2 & 3 & \ddagger \\ 1 & 9 & \\ & & \\ \text { * Spanish "fundamento." } & & \\ \text { \$ Expected frequencies fewer than } 5 . & \end{array}$


A slightly but not significantly larger proportion of respondents in El Zarzal than in Jamundí believed that their crops within the past few years had been "good" (Table 3). Approximately the same proportion of respondents in both villages said that they "did farming in the same manner as their fathers had done it," and "had the same customs as their fathers had." Nevertheless, a significantly larger proportion of the respondents in El Zarzal as compared with those in Jamundí believed that they were "better off" than their parents had been, whereas the respondents in Jamundí were correspo hdingly likelier to say that they were "worse off" than their parents. A slightly but not significantly larger proportion of the respondents in El Zarzal as compared with those in Jamundí believed that the son of a farm worker in this neighborhood had "good" or "fair" possibilities of obtaining lands of his own, in contrast to having "no possibility" of obtaining land.

Upon being asked "In your opinion, who of the following should be in the first place concerned with work toward the improvement of your community?" the respondents in Jamundí in comparison with those in El Zarzal mentioned slightly but not significantly more often "government" and "municipality" instead of "neighbors." Neither was there a significant difference between the two locality groups in answers to the question "To whom do you think in the first place you owe your wellbeing: the priest-the mayor - the neighbors - your relatives - yourself?"

A scale of fatalism was prepared on the basis of 16 items tentatively considered as relevant.

TABLE 3. Chi-Square Test of Significance of Differences Between Answers to Multiple-Choice Questions and Dichotomous Choice Questions in the Two Villages

$$
\mathrm{x}^{2} \quad \text { d.f. } \quad \mathrm{P}
$$

Success in farming depends on the "Saint of your devotion," "knowledge of farming," "weather," etc.

5.032

"Family lineage" or "one's own effort important for one's welfare

"The destiny of man is written," or "man is the master of his destiny"

"Acquiescence" versus "struggle" is important

Number of references to God

Number of references to "luck"

Crops estimated as "good,"

"regular," or "bad"

Farming practiced or not practiced the same way their fathers had done

Thought to have or not to have the same customs as their fathers

Thought to be "better off," "worse," or the "same' as parents in wellbeing

Son of a worker has "good," "fair," or "no" possibility of obtaining lands

"Government," "municipality," or

"neighbors" should be concerned with local improvement

"Priest," "mayor," "neighbors,"

"relatives," or "yourself" as

source of wellbeing

$\begin{array}{lll}5.032 & 4 & <.30 \\ .324 & 1 & <.70 \\ .202 & 1 & <.70 \\ 5.287 & 1 & <.05 \\ 10.524 & 3 & <.70 \\ 2.338 & 3 & <.30 \\ 2.828 & 2 & <.80 \\ .161 & 1 & <.02 \\ .084 & 1 & <.20 \\ 8.297 & 2 & <.30 \\ 3.966 & 2 & <50 \\ 3.206 & 3 & \end{array}$


Four of these* formed a scale in the combined material of Jamundí and El Zarzal. By applying the scale to the data, only a slight, statistically not significant difference was found between the two locality groups. ${ }^{a}$ By introducing years of formal education as an additional variable, the relationship was enhanced within the subgroup of El Zarzal, but not up to the level of statistical significance. ${ }^{b}$ Similarly, by introducing the additional variable of age, the relationship was considerably enhanced within the El Zarzal subgroup, the youngest age groups in El Zarzal showing least fatalistic attitudes, but the differences were still statistically not significant. ${ }^{c}$ But when the additional variable of frequency of visits to Medellín was introduced, the differences were enhanced up to the level of statistical significance. Of the relationships examined, the one between fatalism and the intensity of contacts with the nearby city appeared to be strongest.

\section{DISCUSSION}

The findings indicate that the fatalistic mode of personality adaptation consists of the belief in the will of God, and moral character as explanatory of individual siccess and failure, and of less emphasis on morally neutral learned and rational determinants, such as administration and planning. Fatalism, furthermore, appears to coincide with a pessimistic outlook regarding progress - the element of "despair" seems to be linked with it. Urban influences lessen fatalism; they coincide with a conception of man as a rational being capable of responding to the environment in an individually adaptive

\footnotetext{
*Scalable items were (1) "better" or "equal" in answer to the question, "Do you believe that you now live better, equal, or worse than your parents?"; (2) a maximum of one reference to the "will of God" or "luck" in relation to four selected questions in the questionnaire; (3) endorsement of the alternative, "Man is the master of his destiny," instead of the alternative "Destiny of man is written"; and (4) endorsement of the alternative "Own effort is more important," instead of the alternative "Family lineage is more important" for one's welfare. - Coefficient of reproduction: .93 .

${ }^{\mathrm{a}} \mathrm{X}^{2}-4.552 ;$-d.f. - 4; P .50

${ }^{\mathrm{b}} \mathrm{X}^{2}-9.266$; d.f. - 6; P .20

c $x^{2}-6.756 ;$ d.f. - 3; p 10 .

d $x^{2}-17.971 ;$ d.f. - 6; p 01 .
}

manner, depending on his individual capacity to plan, to administer his affairs, to be economical, and to improve his work technique.

The transition from the fatalistic orientation to the more urban, individualistic and secularized conception of man bears similarity to Weber's characterization of the emergence of the "Spirit of Capitalism." For Weber, the spirit of capitalism signifies emancipation from ethical considerations, the "inner attitude of the adventurer," break with traditionalism, calculation, self-control and frugality. ${ }^{13}$ Durkheim's notion of fatalism - anomie, however, seems to be more useful here than Weber's Spirit of Capitalism. In contrast to anomie, fatalism is the state of society - and the state of mind - where the individual's self-control over his own affairs is lacking, objectively or cognitively, and an extrasystemic frame of reference is employed to explain change. When this state coincides with objective or cognitive impairment of the life situation, fatalism might be expected to manifest itself in antagonism against vaguely defined supraindividual and distant outside agencies held responsible for the individual predicament. The ill-directed hostilities and the lack of unity and direction characteristic of the peasant unrest in parts of Latin America could probably be explained on these grounds. The fatalistic peasants "fight without historical reasons, they fight for the sake of fighting," one observer remarks 14 - "revolutionary form is maintained without revolutionary content." The fatalistic shift of loyalties from one powerful outside structure to another is likely to be an abrupt total and emotional experience rather than the gradual process of internalizing new rules of correspondence involved in learning intra-systemic norms of growing complexity.

The establishing of a statistical relationship between the individual readiness of the peasants to accept new practices and their educational status, for example, easily leads to an overly simplified conception of knowledge and ignorance as the independent variables determining willingness to change. Efforts to induce change, in this approach, are reduced to the mere task of adding useful new items to the arsenal of information the individuals already possess. The theory of fatalism in relation to programs designed to induce change may well prove to be of heuristic value. In the theory of fatalism, the rejection of 
innovation is explained as a contradiction in rationale. Fatalistic rationale deals with agents outside the individual achievement: The peasant feels himself part of a larger society which he is "in" but not altogether "of."15 For the peasant, "God gives the harvest, God takes it away," and epidemics may be divinely willed, thus making vaccination inappropriate. ${ }^{16}$ The peculiarly sudden, disruptive nature of social change in the peasant societies may be understood in terms of a total shift of fatalistic allegiance from one powerful extra-systemic agent to another, when some kind of "disillusionment" - the bankruptcy of the previous total system rationale-is experienced and a new fatalistic allegiance to a new supraindividual structure-perhaps the guerilla - is declared. In contrast to anomia, fatalistic symptoms express themselves in relation to total alternative system rationales, collectively rather than individually. Since fatalism is concerned with dependence on "distant" extra-systemic agents of control, relatively little or no rational preparedness is gained by the fatalistic individual to predict the outcome of the operations of the extra-systemic

${ }^{1}$ The Division of Labor in Society, transl. by George Simpson, The Free Press, Glencoe, Ill., 1960, p. $283 \mathrm{ff}$.

2 Ibid., p. 169.

${ }^{3}$ Suicide, transl. by John A. Spaulding and George Simpson, Routledge \& Kegan Paul Ltd., London, 1952, p. $252 \mathrm{ff}$.

${ }^{4}$ Ibid., p. 253.

5 Ibid., p. 276.

${ }^{6}$ Cf. Bruce P. Dohrenwend, “Egoism, Altruism, Anomie, and Fatalism; A Conceptual: Analysis of Durkheim's Types," American Sociological Review, 24 (August 1959), p. 471.

${ }^{7}$ Functional control and dependence - and functional relationships in general - are taken in this paper to include their factual modus as well as their teleological modus. In the former connotation the existence of a relationship is extracted from the data, in a detached analysis of the variables observed. In the latter connotation the existence of a trait in relation to another is explained by referring to imputed motives and needs of the actors themselves.

${ }^{8}$ Meier and Bell conclude that "anomia is not necessarily confined to the city dweller. In fact, we may expect considerable despair in the near future among members of agricultural, nonindustrial, nonurbanized populations with low living standards - the densely settled "undeveloped areas." Dorothy L. Meyer and Wendell Bell, "Anomia and Differential Access to the Achievement of forces. Attitudes towards change, and attempts to accomplish change, tend to be of emotional, total nature, likely to undergo sudden reversals.

There are, in theory at least, two complementary views of social change in the less developed societies. In the first - an accelerationist view - socioeconomic development is identified with the gradually improving, modernization of the overall productive efficiency of the society, with the diffusion of innovations, and with disseminating technological knowledge. This view gives relatively less attention to the structural discontinuity between, for example, the rural and the urban systems. The second - a structuralist view - departs from the assumption that the total national or international society is not "seamless," and that important discontinuities of means-ends rationale occur along system boundaries. The notion of fatalism may prove to be a conceptual tool stimulating research towards the study of the discontinuities of system rationale, and the structural character of change in this theoretical model becomes emphasized.

Life Goals, American Sociological Review, 24, 1959, p. 201. Orlando Fals Forda maintains that the violence affecting regions of rural Colombia is the outcome of the "impunity and other defects in the judiciary system, the deficient land distribution, illiteracy, the individualism and egocentrism of people, the ethnocentrism of the leading classes...and other anomia provoking conditions." Mons. German Guzman, Orlando Fals Borda, and Eduardo Umaña Luna, "Estudio de un proceso social," Ediciones Tercer Mundo, Monografías Sociológicas No. 12, Facultad de Sociología, Universidad Nacional, Bogotá, 1962, pp. 406-404.

${ }^{9}$ For a study where the addiction to alcohol is taken as an expression of despair characteristic of rural areas rather than towns and cities, see Charles J. Erasmus, Man Takes Control, University of Minnesota Press, Minneapolis, 1961, pp. 262-268.

${ }^{10}$ See Guzman, et. al., op. cit.

11 Social Theory and Social Structure, The Free Press, Glencoe, Ill., 1957, p. 136.

12 For a study where the emphasis of "hard work" has been taken as an index of "Protestant Ethic" see Bernice Goldstein and Robert L. Eichorn, "The Changing Protestant Ethic: Rural Patterns in Health, Work, and Leisure," American Sociological Review, Vol. 26, 4, pp. 557-565. Their study shows that "high work-oriented" farmers tend to be, among others, older and less educated than other groups, also the most likely groups to indicate fear of the physician, they are least likely to 
carry a health insurance policy, to have a small-pox vaccination, least likely to go to their doctors and dentists, least likely to show interest in organized leisure, least likely to employ efficient farm machines and to succeed economically. Even though the level of statistical significance is not reached in my study, it seems to suggest the possibility that the emphasis on "hard work" is a component of the fatalistic complex rather than an indicator of the rational and individualistic orientation. "Hard work" probably is associated by the respondents with the capacity to endure hardships involved in farm labor, and physical capacity, rather than the opposite to "leisure" or "unwillingness to work."
${ }^{13}$ See Max Weber, The Protestant Ethic and the Spirit of Capitalism, translated by Talcott Parsons, George Allen \& Unwin Ltd., London, 1962, p. $58 \mathrm{ff}$.

${ }^{14}$ Luis Antezana E., Lucha entre Cliza y Ucureña, Los Amigos del Libro, Cochabamba, 1960. p. 10.

${ }^{15}$ See Edward C. Banfield, The Moral Basis of a Backward Society. The Free Press, Glencoe, I11., 1958, p. 65.

16 See Orlando Fals Borda, Campesinos de los Andes, Facultad de Sociología, Universidad Nacional, Bogotá, 1961, p. $276 \mathrm{ff}$. 